\title{
BLENDED LEARNING IN HERITAGE CONSERVATION COURSE: CULTURAL MAPPING AND GOOGLE MY-MAPS PLATFORM
}

\author{
Arif Budi Sholihah ${ }^{1 *}$, Johannes Widodo $^{2}$ \\ ${ }^{1}$ Associate Professor, Department of Architecture, Universitas Islam Indonesia \\ Jl. Kaliurang Km 14,5 Yogyakarta, Indonesia \\ ${ }^{2}$ Associate Professor, Department of Architecture, National University of Singapore \\ 4 Architecture Drive, Singapore \\ *Corresponding author; Email: arif.sholihah@uii.ac.id
}

\begin{abstract}
This paper attempts to evaluate the effectiveness of blended learning in Heritage Conservation course, at the Department of Architecture Universitas Islam Indonesia Yogyakarta using both a mini-workshop in a historic district (cultural mapping) and Google My-Maps Platform (digital collaborative) as learning tools to achieve the learning outcomes. The overall finding shows that cultural mapping, as the first-hand information gathering of a heritage district gives the student understanding which then allows the students not only to appreciate the importance of heritage but also having empathy that heritage is not only about artifacts or architecture (tangible assets) but more about people who live in it. Meanwhile, Google My-Maps Platform offers an opportunity for the students to work together in different places and gives the flexibility on the digital learning process both in the heritage district, in the class, and at home. The result from the cultural mapping arranged in the My-Maps in many different forms, such as story/narratives, photos, and videos before producing the report on revealing the "DNA" of the heritage district and can be shared for the benefit of the public. This research has shown that blended learning (online and offline learning) is more effective in architectural education for it is more flexible but still allow the students to get direct experience with the real world.
\end{abstract}

Keywords: Blended learning; heritage conservation; architecture education.

\section{INTRODUCTION}

\section{Heritage Conservation and Architectural Educa- tion in Indonesia}

The heritage conservation movement is not yet considered as a significant concern for architects in Indonesia, whereas in fact: Indonesia is the house for 51 heritage cities (http://www.indonesia-heritage.net/ history, 2012) and the city of Yogyakarta is one of them (Yogyakarta now is in the tentative list of UNESCO World Heritage City awardees). The existence of a historic city, therefore, requires the sufficient expertise of the architects to appreciate, conserve, manage, and re-use it in the context of the contemporary era. It is also very much relevant if we relate it to the Islamic heritage in Indonesia as part of the cultural diversity which so far has been received little attention from the professionals and architectural academia.

In architectural education especially in Indonesia, the knowledge of heritage conservation is also has not been enough delivered to the student, especially at the undergraduate program. However, in heritage conservation, knowledge is not always enough without attitude (values) and skills or psychomotor. In Universitas Islam Indonesia, Heritage Conservation course offered as an elective course for the third year student in four credits. The learning outcome of this course is to understand the history and architectural diversity, able to extract a design concept based on the understanding of the various historical and cultural context of a site; analyze and evaluate them systemically; and apply them concretely in their project, and to assess and make changes or maintain the form or functions of existing buildings to renovate, rebuild, remodel and/or repair.

So far, the outcome of the previous heritage conservation course needs to be improved especially on how to engage the students with historic buildings and the district, and to give them understanding that heritage is not only about building/artifacts but more than that, heritage is about people, not a commodity; it is about empathy and empowerment (Widodo, 2017). By seeing heritage as a Historic Urban Landscape that sees the historic area as the result of a historic layering of cultural and natural values and attributes, extending beyond the notion of "historic centre" or "ensemble" to include the broader urban context and its geographical setting. It includes topography, geomorphology, hydrology, and natural features, its built environment, both historical and contemporary, its infrastructures above and below ground, its open spaces and gardens, its land use patterns and spatial organization, perceptions and visual relationships, as well as all other elements of the urban structure. It also includes social and cultural practices and values, economic processes and the intangible dimensions of 
heritage as related to diversity and identity. This definition provides the basis for a comprehensive and integrated approach for the identification, assessment, conservation, and management of historic urban landscapes within an overall sustainable development framework (UNESCO, 2011).

The other problem is the effectiveness of the delivery method, which still relies on traditional method (full classes and lecturer as centre of the teaching process). There is a need to improve the technique which more on Student-Centered Learning and more innovative especially regarding the digital media (online learning). This study aims to evaluate the effectiveness of blended learning in Heritage Conservation course, at the Department of Architecture Universitas Islam Indonesia Yogyakarta using both a mini-workshop in the real world (cultural mapping) and Google My-Maps Platform as a learning tool to achieve the learning outcome.

\section{Blended Learning as Learning Method}

The terms "blended learning," "hybrid learning," "technology-mediated instruction," "web-enhanced instruction," and "mixed-mode instruction" are often used interchangeably with each other in various literature (Martyn, 2003). Blended Learning (BL) combines traditional classroom in "brick and mortar" schools and online with digital media. BL model is a program in formal education aims to: 1) Students learn part through online learning with computermediated activities (Blended Course Design, 2017), 2) Students learn partly in the classroom (face-toface), and 3) Students learn in a unified course by providing some integrated learning experience.

In the Blended Learning method, there are four models, namely Rotation, Flex, A La Carte, and Enriched Virtual (Horn, 2014). Rotation Model is designed where students are rotated on a fixed schedule between face to face and online learning. There are various activities such as small-group discussion, group projects, individual tutoring, and class assignments in the form of handwriting (pencil and paper assignment). Students mostly study in the classroom; except for homework assignment can be rotated in a station, in the laboratory, and a flipped classroom (combination between the classroom and online learning). Flex model is a model with online learning becomes the backbone of student learning, although it is also held an offline class. Students mostly study on campus, except for homework. Faceto-face between students and lecturers is done flexibly and adaptively as needed. Face-to-face learning is conducted with group discussions, group assign- ments, and individual guidance. A La Carte Model is a model with learning activities are fully conducted online.

Nevertheless the students keep taking other courses offline, so the student position remains on campus. This model is to differentiate with online learning like in an Open University. In addition, Enriched Virtual Models is designed to have face-toface sessions but may perform tasks remotely. Online learning will be the backbone of education when students are away from campus. The same person acts as a lecturer on face-to-face and online learning.

Blended learning is believed to be more effective than pure face-to-face learning (Top 5 Benefit Blended Learning, 2015). It can help students achieve their best potential through the possibility that students can work according to their habits and for lecturers can also provide support individually (Garrison \& Kanuka, 2004; 5 Benefit Blended Learning, 2016). It also parallels with the findings that ICT assistance can improve the quality of student behavior in the learning process (Alexander, 2010). Blended learning allows students to work personally on their workstations, to combine with the model of the classroom of expectation that all students expect to live at the same time and speed (Five Benefit of Blended Learning, 2016). The advantage of using the Blended Learning model is largely determined by the quality of the implementation of this model itself, i.e., when the model can facilitate student learning, communicate ideas effectively, show interest in learning and continue to show progress in their learning. Meanwhile, the weakness of this model is the high dependence on ICT network quality; some previous research shows the quality of the ICT network to be the determinant of the success of BL model (Alexander, 2010).

\section{Kampung Kauman Heritage District as Case Study}

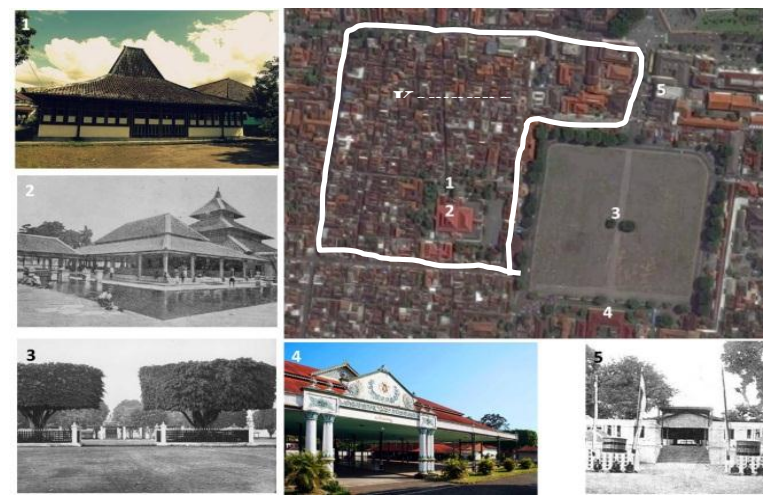

Fig. 1. Kauman in the context of Yogyakarta (Source: Author, 2017; Tropenmuseum.nl) 
The word Kauman refers to the word 'kaum' or Islamic leaders (Mulyati, 1993). The name Kauman usually used by regencies and municipalities in Java to name an area where religious Muslim communities are concentrated, and is usually located on the west side of a town square with a mosque adjacent to the square. Figure 1 shows Kampung Kauman in the context of Yogyakarta. It is situated in the inner city of Yogyakarta as an indispensable part of the Great Mosque (Masjid Gede Kauman). The imperial city of Yogyakarta follows the ancient concept of Javanese city (Catur Gatra Tunggal Concept) consists of four main elements, i.e., the palace, the square, the market, and the mosque.

Historically, kampung Kauman is the house for the Muslim community who serve as the royal servant to hold Islamic ceremonies, festivals, etc. Until now all members of society in Kauman are Muslim. In the early twentieth century (1912) Kampung Kauman is the place of birth for Muhammadiyah, which now a second biggest Islamic organization in Indonesia aims to purify Islam based on $\mathrm{Al}$ Qur'an and Hadith from syncretism and mystical. In 1946 Dalem Pengulon, the House of Kauman Leader (Penghulu) is the place of birth of Universitas Islam Indonesia after moved from Jakarta. Kauman is also a centre of Batik industry which reaches its peak in the 1950s. Kampung Kauman is also well-known as an Endogamy community that encourages inter-marriage amongst the community member within the kampung. However, nowadays the specialty of Kauman as historic area seems to be neglected and getting least attention from the government as well as academia.

\section{METHODOLOGY}

To evaluate the effectiveness of blended learning in Heritage Conservation course, at the Department of Architecture Universitas Islam Indonesia Yogyakarta this study utilises both cultural mapping and Google My-Maps Platform as learning tools. Cultural Mapping in the heritage district as face to face learning apart from the class meeting utilized to helps the students understand and have empathy on how heritage conservation should be conducted. Cultural mapping, also known as cultural resource mapping or cultural landscape mapping concerned about safeguarding cultural diversity give to a wide range of research techniques and tools used to "map" distinct peoples' tangible and intangible cultural assets within local landscapes around the world (UNESCO, 2010). Cultural mapping is an emerging interdisciplinary field in which a range of perspectives are used as a mode of inquiry and a methodological tool in urban planning, cultural sustainability, and community development that makes visible the ways local stories, practices, relationships, memories, and rituals constitute places as meaningful locations (Duxburry, et al., 2015). In the context of this research, cultural mapping is done through listening to the voices from the ground with empathy, re-telling the community's narratives with rationality. A city can be regarded as palimpsest; every layer has its own story and history that needs to be revealed to keep the city's history alive. Kauman heritage district as the case study can be seen as a complete human "body" with "mind" and "soul". Through cultural mapping we are learning to analyse the state of health of Kauman's "body, mind, and soul"; finding the "meridian points"; and proposing a "holistic healing" for the better future.

Google My-Maps Platform as an online learning tool is utilized to produce the result of the cultural mapping which can be done by the students as collaborated online student assignment that can be done in the classes, laboratory, field observation, and at home. The online learning is also being supported by the Google Classroom as media to upload the MyMaps, to share class modules, and student assignments. The final class products (portfolio and Google My-Maps), Midterm Exam and Final Exam are used as the analysis tools to evaluate the learning outcome.

To assess the effectiveness of the course methods, the evaluation takes place in several different aspects, namely:

Table 1. Student's Performance Indicator Target

\begin{tabular}{llrr}
\hline No Performance Indicator & Baseline & Target \\
\hline 1 & Attendance percentage & $61.2 \%$ & $80 \%$ \\
\hline 2 & Number of studens with >=B grade & $45 \%$ & $60 \%$ \\
\hline
\end{tabular}

At the end of the course, testimonials from the students regarding the teaching process also conducted through interviews, and written testimony as students feedback to the lecturer and department as part of the quality assurance in Universitas Islam Indonesia.

\section{RESULTS and DISCUSSION}

\section{The Course Preparation Process}

Preparation of the learning process begins by setting up the lecture room according to the suggested layout for the method of Student-Centered Learning. Preparation is also undertaken to select the location of field workshops appropriate to the learning objectives. From some of the locations considered, Kauman Kampung was appointed with several considerations: 
1) an Islamic Heritage area (very compatible with Islamic values of UII). 2) having a high historical value but still gained little attention from the government and scholars. 3) inseparable part of Yogyakarta inner city. 4) spatially the kampung is not too wide, so it can be studied by the students of the class (22 students).

Another preparation is the lecture modules prepared for 14 meetings. International partners (foreign lecturers) play an active role in the development of weekly materials and actively share the latest library and data on heritage conservation via email and share through other platforms including LINE Group with students.

\section{The Teaching Learning Process}

Figure 2 shows the teaching-learning process in the early phase of the course. At the session one to session five, most meetings are held in the class with Student-Centered Learning method to give the students insight and understanding on heritage conservation definition, principles, practices, procedures, and techniques. During this phase, Google Classroom Platform was used to share the modules, and LINE group was actively used as media for online discussions apart from the class discussions. The class was conducted bi-lingual (English and Bahasa Indonesia) as part of the aims of the course is also to enhance the ability of students to engage in class activities in English. At the second phase of the course (session 6-9) is a field workshop involving international lecturer. It started with the presentation of the Historic Urban Landscape Method developed by UNESCO and observation methods for this program. At the later phase of the course (session 1014), the activities return to campus and classroom meetings method is the studio to formulate the result of the workshop, understanding and assessment of heritage assets of Kauman. The reports produced during this stage and the student start to brainstorm the design ideas for the future of Kauman heritage district. The report is formulated in a book, and the students also produce Google My-Maps for Kauman. The entire series of lectures ended with a final presentation at session 14 .

\section{The Cultural Mapping}

The cultural mapping is intensively conducted during the workshop, which involved key persons from the community, including formal leader (Rukun Warga Chief) and informal leader (Mosque Board Member and Respective Community Members). The Pendopo (Public Hall) of Dalem Pengulon is appointed as the base camp for the whole workshop activities. At the first stage of the mapping process, the students follow some lecture series from the lecturers on mapping techniques and start to do the observation on day 1 . They divided into four groups; each of them observes an area called one Rukun Warga (RW), as Kauman comprises four RW. The observation activities include documenting the events and the urban fabrics, taking notes on essential findings, interviewing people, and experiencing the spaces with their full senses (visual, audio, tactile, taste, etc.) (see figure 3 ).

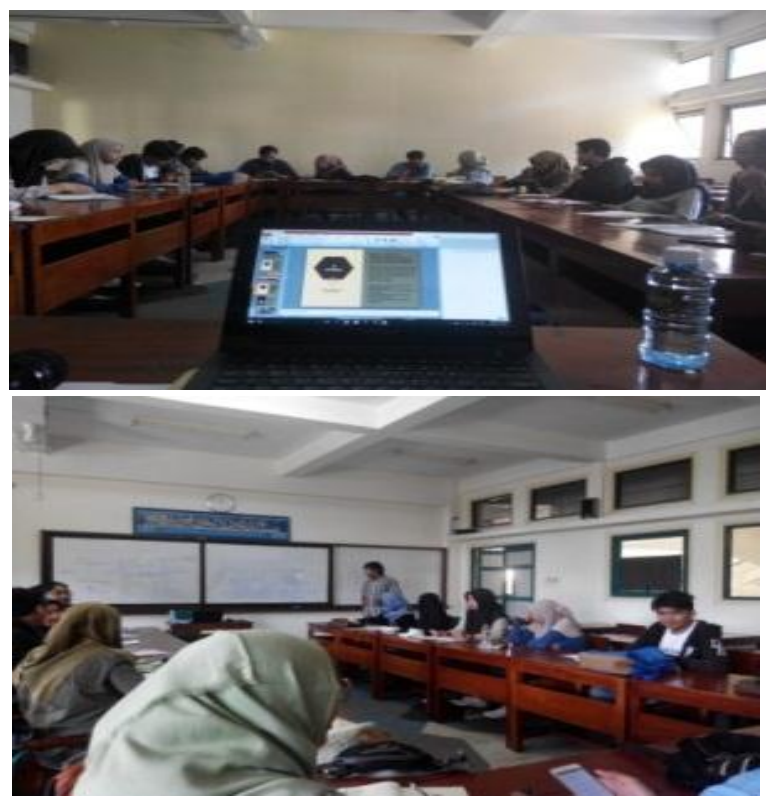

Fig. 2. Teaching and Learning Process: Class Activities

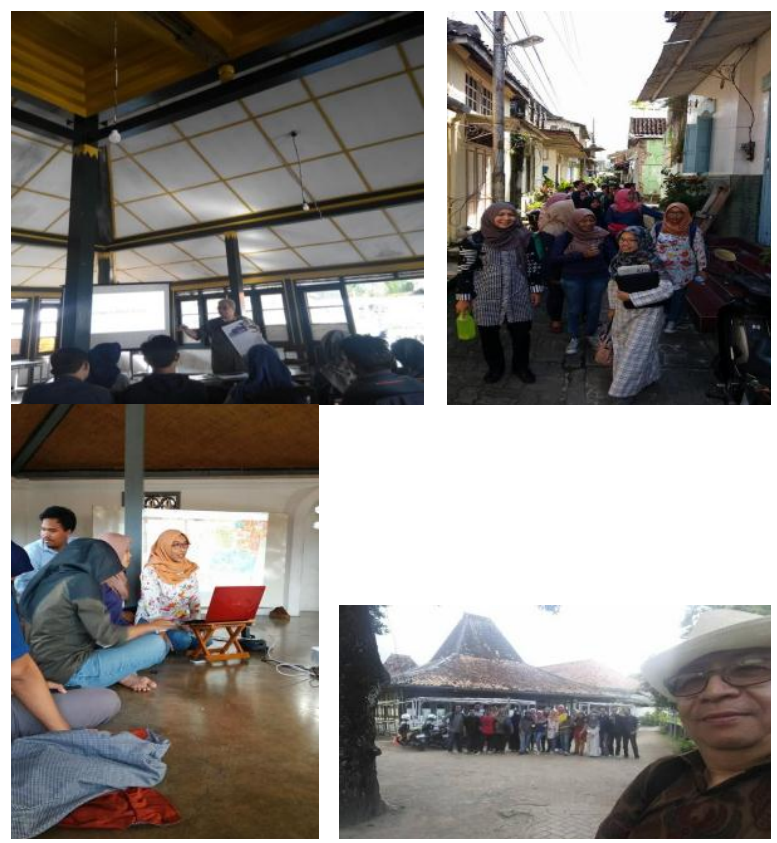

Fig. 3. Teaching and Learning Process: Cultural Mapping \ 
Google My-Maps as Online Learning Tool

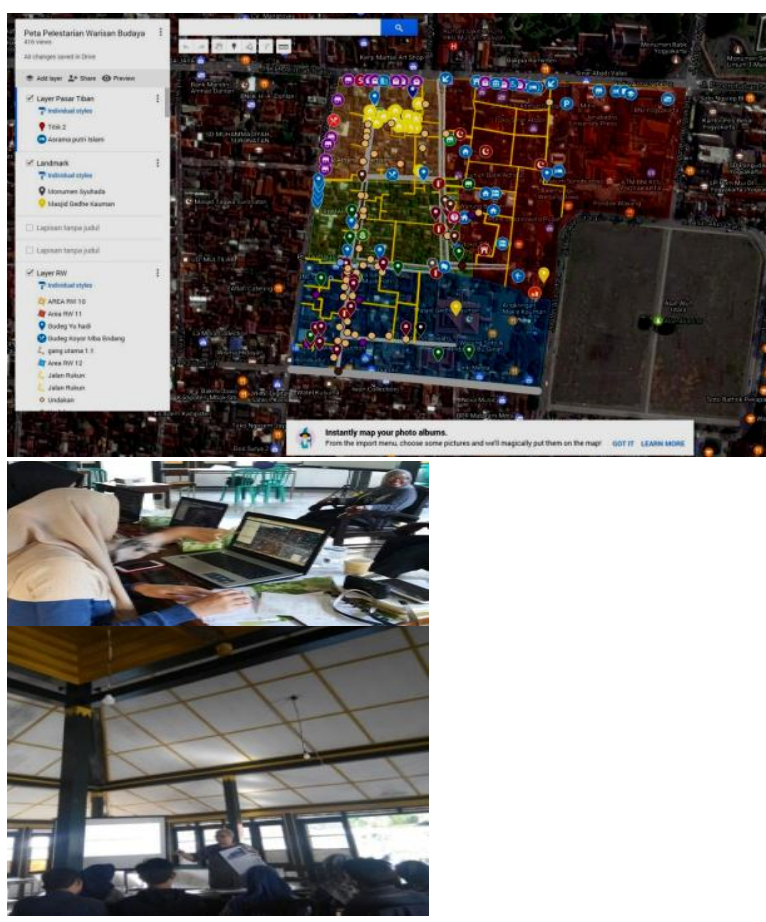

Fig. 4. Google My-Maps Platform

As part of the blended learning tool, Google MyMaps (as shown in Figure 4) is utilised after the cultural mapping process. The students gather their first-hand information and then uploaded through My-Maps in order to share information not only to the other member of the class but also, in the end, can be used by the general public. The data that can be shared comprises of text as the result of the observation and interviews to the local community, photographs were taken by the students and local community collections, as well as videos that make the My-Maps, helps a lot to compile all the data of Kauman historic district. The flexibility of online learning is valuable for the students to allow them to study from places out of class and in different times, which cannot be conducted via "brick and mortar class" method. The My-Maps also helps to re-telling the community narratives with rationality by allowing it can be seen and edited by the lecturers as well as other members of the class. So in the end, the real "health" condition of the Kauman historic district can be portrayed through cultural mapping and My-Maps platform. Thus, regarding the heritage conservation process adopted by UNESCO (Historic Urban Landscape Approach) this process can be seen as the identification and assessment process before coming up with the conservation strategy, based on participation and management in a more formal process. (see figure 5).
MANAGEMENT

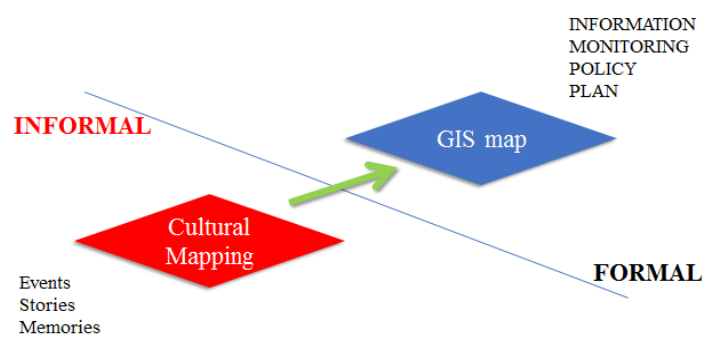

PARTICIPATION

Fig. 5. Cultural Mapping and GIS Map (including Google My-Maps) for Conservation Plan

\section{Lesson Learnt}

The learning outcomes show that there is an increase in student attendance and enthusiasm to keep up with the lectures. Usually, it is difficult to maintain the presence and involvement of students in elective courses because they feel they can take other elective courses if it is not quite fit with their interests. However, this does not occur in this course. The student attendance has achieved $88.17 \%$ of the $80 \%$ as the target. Another strong indicator of the program is the number of students who get grade $>=\mathrm{B}$ reached $88.2 \%$. This achievement is quite far from the expected target of $60 \%$.

It is important to note that the results of the Final Exam Semester and Final Assignment showed a significant increase in value compared to the assignment and Mid Term Exam. This achievement is suspected because the successful method developed in Cultural Mapping is that to grow "empathy" to the students to be more willing to understand the meaning of heritage through direct contact into the field through cultural mapping. Another thing that is suspected to be the cause of the high achievement of learning is the Blended Learning method gives students the flexibility to do the tasks in an online collaboration (Google My-Maps Platform) so that it can be done anywhere and anytime according to the wishes and character of each student. The findings are consistent with the blended learning is believed to be more effective than pure face-to-face learning since it allows the students to work personally on their workstations and collaboration is made online (Alexander, 2010). Furthermore, the cultural mapping that allows the students to have direct experience with real life makes them understand empathy and makes them more "human." The further question is how to formulate the best percentage on how much the online learning and offline learning (classes and field observation) should be formulated. 
In Kauman students found many heritage assets, some are abandoned and even dismantled. Interviews with the surrounding communities also create WOW moments for them, after doing interviews and interact with the locals. As far as they concern, heritage is mainly about physical elements, but after listening to people's stories and talking with them, it raised their feeling on empathy with the residents, sadness with the existing conditions, and fond of the heritage district. Some comments from the students, such as:

... 'from this course I learned that heritage is not only about building to be preserved and studied, but from this course we have a comprehensive new insights about how we empathize and sympathize, listening to someone's story of the past, to understand about history of a place and take a closer look at one's life as well as their ancestor and origins ... '(Triadita Yuliandari NIM: 13512114)

... From this course is I began to love and respect the cultural heritage in Indonesia, studying heritage was not boring, instead, we are reintroduced to something that ever existed or historic in Indonesia ...' (Ibnu Johdi haves, NIM: 11512146)

\section{CONCLUSION}

This research has shown that blended learning (online and offline learning) is more effective in architectural education for it is more flexible but still allow the students to get direct experience with the real world. The half-half combination between the two methods can be implemented in order to achieve the best result of the course learning outcomes. In this case, real life experience/offline (class meeting and cultural mapping) is conducted in advance before the online learning (Google My-Maps Platform) is performed to allow the students more flexible to collaborate in the online platform within their customised way of learning (flexible in time and places).

This action research also recognizes the importance of heritage conservation to be taught at the department of architecture especially in undergraduate level since it is very much relevant to the Indonesian context. As also happens in other Asian cities, Indonesian cities are now at the crossroads between continuity and change, between conservation and rapid development. It is also important to address this course as a lesson learned for other courses especially regarding the course delivery method especially in architectural education in Asia.

The limitations of this course are in terms of product students have not been fully able to demonstrate the skills of design intervention in heritage buildings, but still limited to ideas and design ideas only. This is because the process of understanding the socio-cultural context, local narratives, and identity of the place ("DNA") takes longer time than what is predicted. Nevertheless, outcomes from this course are some students using the results of this course to further deepen their study on the subjects of Scientific Writing and architectural design in the Final Project of Bachelor Degree.

\section{ACKNOWLEDGMENT}

This program is funded by the International Collaborative Class supported by the Teaching Grant Program, Academic Development Board, Universitas Islam Indonesia in partnership with Associate Professor Johannes Widodo, Department of Architecture, National University of Singapore.

\section{REFERENCES}

Alexander, S. (2010). "Flexible Learning in Higher Education". In Penelope Peterson; Eva Baker; Barry McGaws. International Encyclopedia of Education (Third ed.). Oxford: Elsevier. 441-447. doi:10.1016/B978-0-08-044894-7.00868-X. ISBN 9780080448947.

Amstrong, P. (2017). Bloom's Taxonomy, Center for Teaching-Vanderbilt University, https://cft.vanderbilt.edu/guides-sub-pages/blooms-taxonomy/ retrieved January 2017

Bonk, C.J., \& Graham, C.R. (2006). The handbook of blended learning environments: Global perspectives, local designs. San Francisco: Jossey-Bass/ Pfeiffer. 5.

"Five benefits of blended learning - DreamBox Learning". Dream Bo Learning. Retrieved 201601-28.

Garrison, D.R., \& Kanuka, H. (2004). "Blended learning: Uncovering its transformative potential in higher education". The Internet and Higher Education, 7, 95-105. doi:10.1016/j.iheduc.2004. 02.001

Hannafin, M.J. (1992). Emerging technologies, ISD, and learning environments: Critical perspectives. Educational Technology Research and Development, 40(1), 49-63.

Hannafin, M.J., \& Land, S.M. (1997). The Foundations and Assumptions of Technology-Enhanced Student-Centered Learning Environments, Instructional Science, 25, 167-202.

Hannafin, M.J., \& Hannafin, K.M. (2010). Cognition and student-centered, web-based learning: Issues and implications for research and theory. In Learning and instruction in the digital age (1123). Springer US. 
Harsono (2008). Student-Centered Learning di Perguruan Tinggi, Jurnal Pendidikan Kedokteran dan Profesi Kesehatan Indonesia, 3(1), 4-8.

Johnson, E. (2013). The Student Centered Classroom: 1: Social Studies and History. 19. ISBN: 1317 919491.

Martyn, M. (2003). "The hybrid online model: Good practice". Educause Quarterly, 18-23.

Michael, B.H., \& Heather, S. (2014), Blended: Using Disruptive Innovation to Improve Schools (San Francisco: Jossey-Bass).

Overby, K. (2011) Student-Centered Learning, ESSAI: 9, Article 32. Available at: http://dc.cod. edu/essai/vol9/iss1/32
"Top 5 Benefits of a Blended Learning Platform". Retrieved 2015-07-04.

UNESCO Bangkok (2010) "Cultural Mapping" webpage Accessed 21 December 2010

Duxbury, N., Garrett-Petts, W.F., \& MacLennan, D. (Eds) (2015) Cultural Mapping as Cultural Inquiry Routledge Advances in Research Methods Routledge, May 22, 2015, ISBN: 9781317 588009

Wright, G.B. (2011). "Student-Centered Learning in Higher Education" (pdf). International Journal of Teaching and Learning in Higher Education, 23(3), 93-94. ISSN: 1812-9129.

http://www.indonesia-heritage.net/history, 2012. 